\title{
COVID-I9 lockdown impact on the mental health of students: need to start a mental health cell
}

\begin{abstract}
Mental health of the students is the topic of interest throughout the world. The entire performance of the student depends on his mental health. Till date there is no proven treatment to manage the Novel corona virus disease. As the rate of spread is increasing day by day, lockdown is the only option available to slowdown the rate of spreading the infection. The examinations were postponed due to the lockdown effect and the actual date of exam is awaited. In this context many students were undergoing mental stress and there is a strong need to consider their mental health status. There is need of psychiatrist, in this context to keep the mental balance of the students. Every educational institution may think of establishing a mental health cell that comprises of a psychiatrist or psychologist and dean and senior faculty members of the institute. The authors would like to urge each educational institution to think of starting a mental health cell for the benefit of the students in general.
\end{abstract}

Keywords: mental health, students, novel corona virus disease, lockdown
Volume 7 Issue 2 - 2020

\author{
Sai Sailesh Kumar Goothy,' Srilatha Goothy, ${ }^{2}$ \\ Anita Choudhary,' Potey GG, ${ }^{2}$ Manju \\ Purohit, ${ }^{3}$ Hirok Chakraborty, ${ }^{\prime}$ Ashish \\ Pathak, ${ }^{4}$ Mahadik VK ${ }^{5}$ \\ 'Department of Physiology, RD Gardi Medical College, India \\ ${ }^{2}$ Department of Bio-chemistry, RD Gardi Medical College, India \\ ${ }^{3}$ Department of Pathology, RD Gardi Medical College, India \\ ${ }^{4}$ Department of Pediatrics, RD Gardi Medical College, India \\ ${ }^{5}$ Medical Director, R. D. Gardi Medical College, India
}

Correspondence: Sai Sailesh Kumar Goothy, Associate Professor Department of Physiology, RD Gardi Medical College, Ujjain, Madhya Pradesh. India, Tel 7382075279, Email dr.saisailesh@gmail.com

Received: April 20, 2020 | Published: April 30, 2020

\section{Opinion}

Mental health of the students is the topic of interest throughout the world. The entire performance of the student depends on his mental health. Disturbances in the mental health not only have negative impact to the particular student but also have serious negative impacts on the community, as today's student is the future of the country contributing to its development by serving various roles like teacher, engineers, doctors, nurses etc. Hence, the mental health of the students has to be given at most importance.

Till date there is no proven treatment to manage the Novel corona virus disease. As the rate of spread is increasing day by day, lockdown is the only option available to slowdown the rate of spreading the infection. In this process, all the education institutes were also locked down all of sudden. The students were in different phases of their academic year like some are about to complete the academic year, some are about to write their entrance examinations and some are writing their examinations. It is well known that the students experience lots of stress especially before and during the examinations. ${ }^{1}$ The examinations were postponed due to the lockdown effect and the actual date of exam is awaited. In this context many students were undergoing mental stress and there is a strong need to consider their mental health status. ${ }^{2}$ The students were preparing the examinations especially the entrance examinations for years together. For example, in India, NEET is the common entrance examination to enter into the professional colleges. Students will be preparing for this exam since two years as the scores will decide their admission criteria. Some students might be allotting an extra year to get through the entrance examinations. All these students are in high stress because their pre examination period will continue till they complete the examination. Further, as there is no announcement of the date of examination, there is quiet uncertainty about their future. To this, parents may add up more stress on their children as they are equally undergoing stress regarding the career of their kids. Though many of the educational institutes have launched online classes, adaptation of the student to the sudden transition from routine teaching method is stressful. This is true especially in case of the slow learners. Further, the fear of corona disease will add up to their stress.

There is need of psychiatrist, in this context to keep the mental balance of the students. ${ }^{3}$ Every educational institution may think of establishing a mental health cell that comprises of a psychiatrist or psychologist and dean and senior faculty members of the institute. Regular online counseling can be planned along with the online classes. It is equally important to counsel the parents along with the students. Regular monitoring of the stress levels using the online tools can be done to prevent the student to enter into the state of depression. Simultaneously the teachers should also be counseled in handling the students during the online classes. The student should ensure that there will not be any loss of year. The entrance examinations may be planned to conduct online as majority of the universities throughout the world is already following the same. The cell will also monitor the students even after the lockdown as it takes time for the students to normalize himself after the long, unexpected break of his studies. Continuous monitoring, offering counseling to the needy students will help to keep the students mentally health and do well in personal and professional life. The authors would like to urge each educational institution to think of starting a mental health cell for the benefit of the students in general.

\section{Funding statement}

Self-funding.

\section{Contributors}

All authors contributed equally.

\section{Conflicts of interest}

None declared. 


\section{Acknowledgement}

None.

\section{References}

1. Singh R, Goyal M, Tiwari S, et al. Effect of examination stress on mood, performance and cortisol levels in medical students. Indian $J$ Physiol Pharmacol. 2012;56(1):48-55.
2. Psychologists study impact of lockdown on young people. 2020.

3. Looking after your mental health during the COVID-19 lockdown. 2020. 